\title{
Evaluating Fungicides and Biofungicide for Controlling Cercospora Leaf Spot on Marigold
}

\author{
Sunita Chandel and Vijay Kumar* \\ Department of Plant Pathology, Dr Y S Parmar University of Horticulture and \\ Forestry, Nauni, Solan (HP) - 173230, India \\ *Corresponding author
}

\begin{tabular}{|c|c|}
\hline & A B S T R A C T \\
\hline $\begin{array}{l}\text { Ke y w or d s } \\
\text { Cercospora, } \\
\text { Fungicides, } \\
\text { Biofungicides, } \\
\text { Marigold. }\end{array}$ & \multirow{3}{*}{$\begin{array}{l}\text { The field trials were conducted at the experimental farm of the Department of Plant } \\
\text { Pathology, Dr Y S Parmar University of Horticulture and Forestry, Nauni, Solan during } \\
\text { the period } 2014 \text { and } 2015 \text {. A total nine fungicides and five bio-formulations were screened } \\
\text { for their efficacy in controlling the Cercospora leaf spot disease of the marigold. Bavistein } \\
\text { and Captan gave the best disease control and the disease severity recorded were } 12.37 \% \\
\text { and } 17.41 \% \text { respectively. Lesser disease reduction was recorded in Cabriotop (18.58\%), } \\
\text { Acrobat ( } 21.10 \%) \text {, Insignia (24\%), Alitte ( } 25.28 \%) \text {, Metiram (26.93\%), Matco (28.03\%) } \\
\text { and Antracol (30.36\%). Among bio-formulations Garlic Extract + Cow urine +Soap Nut, } \\
\text { cow urine and garlic extract were found best with the disease severity viz. 15.36\%, 18.07\% } \\
\text { and } 19.61 \text { respectively. While the least effective bio-formulation were field formulation } \\
(31.10 \%) \text { and soap nut (32.13\%). }\end{array}$} \\
\hline Article Info & \\
\hline $\begin{array}{l}\text { Accepted: } \\
\text { 19 April } 2017 \\
\text { Available Online: } \\
10 \text { May } 2017\end{array}$ & \\
\hline
\end{tabular}

\section{Introduction}

Marigold (Tagetes erecta L.), a member of the family Asteraceae or Compositae, is a potential commercial flower that is gaining popularity on account of its easy culture, wide adaptability, and increasing demand in the Indian subcontinent (Asif, 2008). Margold is very important ornamental plant cultivated in the gardens as winter annual plant. It is one of the most valuable medicinal plants and the pigment of flowers is used in food colorings. Moreover, marigold plants are considered a very valuable crop for controlling plant parasitic nematode as recorded by Basu and Roy (1975). The aerial parts of the plant contain high quality of essential oil that can be used for scenting soaps, perfumery,
Cosmetic and pharmaceutical industries. Marigold is one of commercially exploited flower crop. Marigold is grown for cut flowers, garlands, decoration besides used in landscape gardening.

Marigold infected with fungal, viral and bacterial diseases, among which the fungal disease, flower blight caused by Alternaria zinniae Pape, wilt and stem rot (Phytophthora cryptogea), Collar Rot (Phytophthora sp.; Pythium sp.), Damping Off (Pythium sp.), Alternaria leaf spot, Fusarium wilt (Fusarium oxysporium) and Cercospora leaf spot (Cercospora megalopotamica) (Pawar, 1971). Cercospora leaf spot disease causes the 
economic losses in term of yield and quality parameters. Typical foliar symptoms of Cercospora leaf spot are circular spots about $1 / 8$ inch in diameter with ash gray centers and dark brown or reddish-purple borders. In quest of getting high flower production, excess usage of fungicides lead to fungicide resistance in the pathogens (Gangavane, 1981; Arora et al., 1992; Waghmare et al., 2011).

Fungicides also directly or indirectly affect the environment and human health besides disturbance to the ecological balance. In the present investigation was carried out to find out the most effective fungicide for controlling the Cercospora leaf spot disease. Along with fungicides we had tried to find out the alternate methods for controlling the disease by evaluating the bio efficacy of certain bio fungicides.

\section{Materials and Methods}

The field trials were laid out at the experimental farm, dept. of Plant Pathology, Dr. Y S Parmar University of Horticulture and Forestry, Solan, Himachal Pradesh, India during the year 2014 and 2015 to evaluate the efficacy of fungicides and biofungicides. The experiment was conducted in randomized block design (RBD) with nine fungicides treatments and five biofungicides with three replications of each treatment.

Fungicides used for spraying were viz. Bevistein@0.1\%, Captan @.2\%, Cabriotop @0.1\%, Acrobat@0.1\%, Insignia@0.1\%, Alitte@0.1\%, Metiram @0.1\%, Matco $@ 0.1 \%$ and Antracol @ $0.1 \%$ respectively. The biofungicides evaluated were garlic extract + cow urine +soap nut, cow urine, field formulation and garlic.

All biofungicides were applied in the field at the concentration of ten per cent. Plot size of
$3 \times 3.5 \mathrm{~m} 2$ was maintained per treatment. All the cultural practices were applied as per package of practices. Spraying was taken up immediately after disease appearance. The observations on per cent disease severity were recorded by using 0-12 scale as given in table.1 (Horsfall and barratt, 1945).

Per cent disease severity was calculated by using the formula given by McKinney (1923).

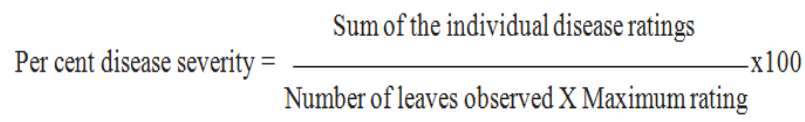

Statistical analysis was done with using the standard procedure described by Gomez and Gomez (1986).

\section{Results and Discussion}

Present study was carried out to evaluate the different fungicides and bio-formulations as foliar sprays against the Cercospora leaf spot of the marigold. Disease was start appearing after 22 day of transplanting of seedling. A total of 3 sprays were given starting after disease initiation at 10 days intervals. It is clear from the data presented in the table 2 that the bavistin was found most effective with the disease severity $12.47 \%$ sprayed at concentration of $0.1 \%$, which is followed by the captan with disease severity $17.41 \%$ sprayed at concentration of $0.2 \%$.

The highest disease severity was also recorded in Cabriotop (18.58\%), Acrobat (21.10\%), Insignia (24\%), Alitte (25.28\%), Metiram (26.93\%), Matco (28.03\%) and Antracol (30.36\%) when compared with control $(62.07 \%)$. The data presented in the table 3 revealed that the bio-formulation garlic extract + cow urine +soap nut, cow urine and garlic extract were found best with the disease severity viz. 
Table.1 Horfall and barratt scale

\begin{tabular}{|c|c|c|c|c|c|c|c|c|c|c|c|c|}
\hline Rating & 1 & 2 & 3 & 4 & 5 & 6 & 7 & 8 & 9 & 10 & 11 & 12 \\
\hline $\begin{array}{c}\% \\
\text { Infectio } \\
n\end{array}$ & 0 & $\begin{array}{l}0- \\
3\end{array}$ & $\begin{array}{l}3- \\
6\end{array}$ & $\begin{array}{l}6- \\
12\end{array}$ & $\begin{array}{l}12- \\
25\end{array}$ & $\begin{array}{l}25- \\
50\end{array}$ & $\begin{array}{l}50- \\
75\end{array}$ & $\begin{array}{l}75- \\
87\end{array}$ & $\begin{array}{l}87- \\
94\end{array}$ & $\begin{array}{l}94- \\
97\end{array}$ & $\begin{array}{l}97- \\
100\end{array}$ & 100 \\
\hline
\end{tabular}

Figure.1 Symptoms of Cercospora leaf spot

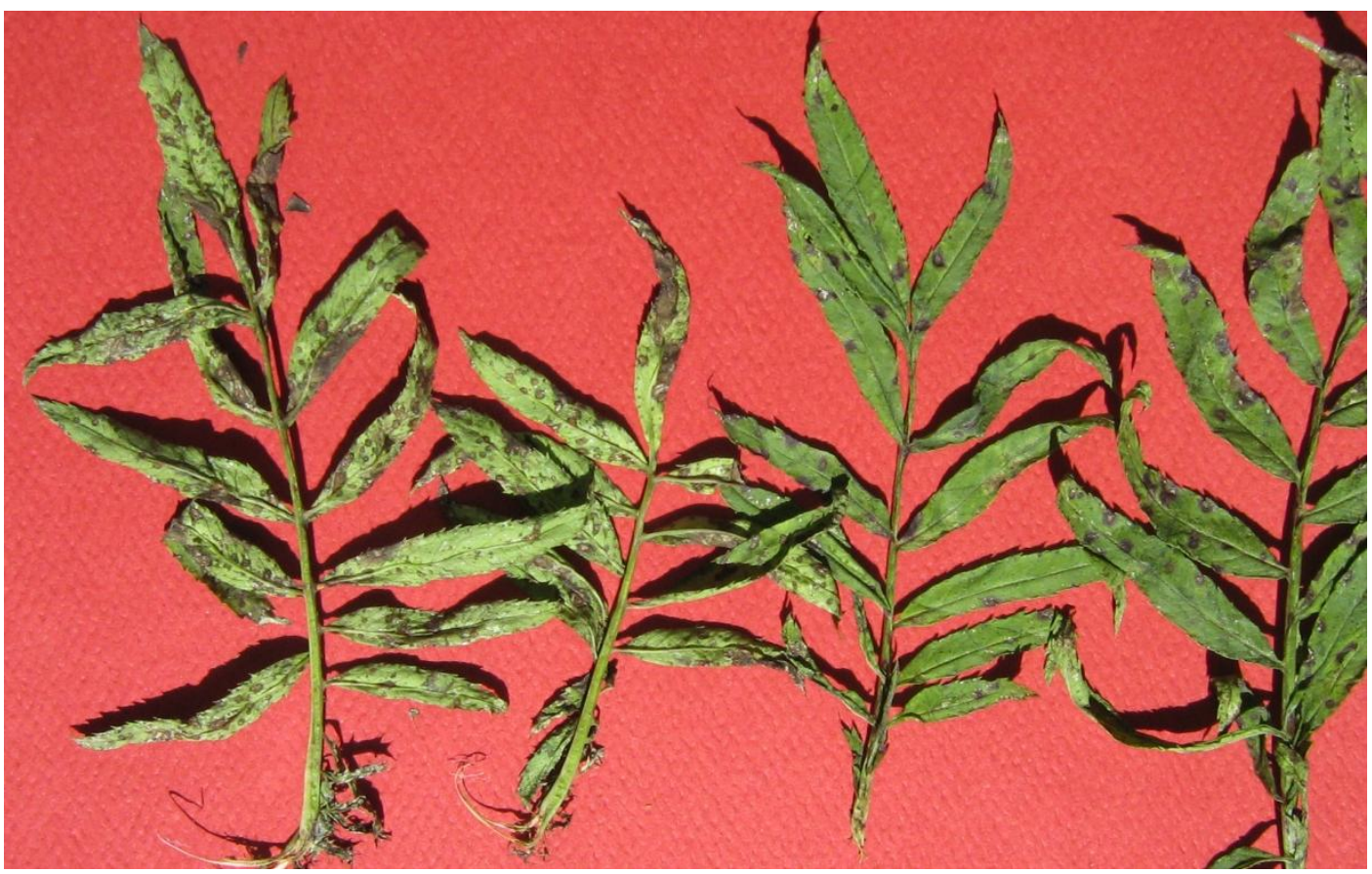

A. Bio-formulation treated plants of Marigold

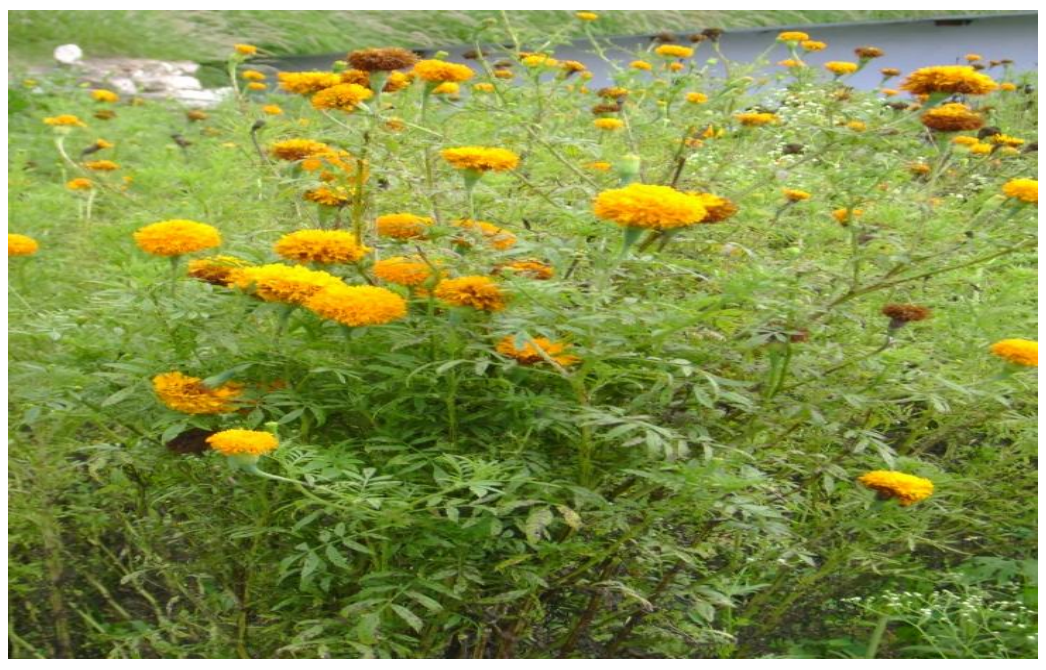


B. Fungicides treated plants of marigold

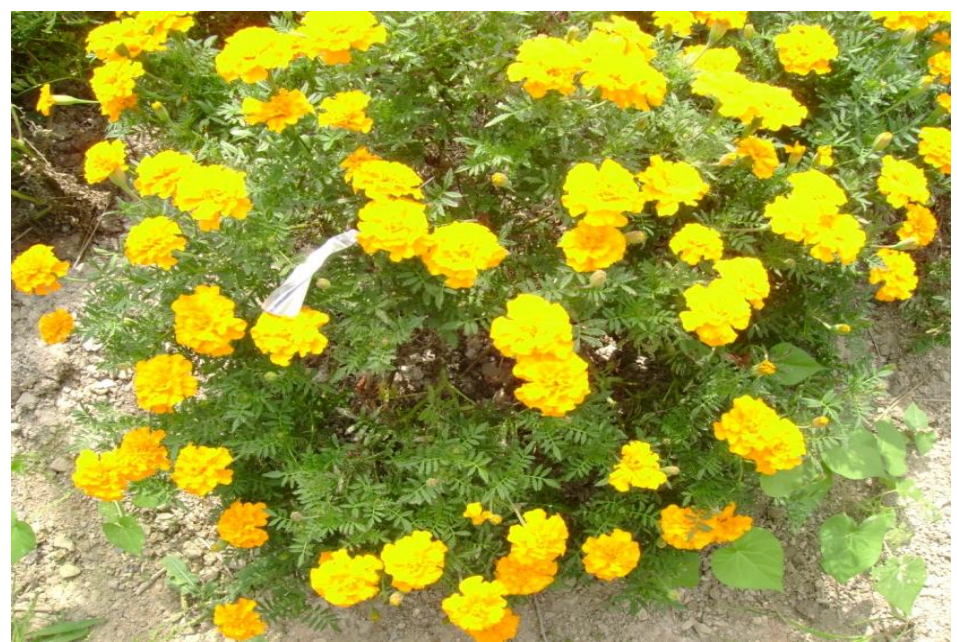

C. Control (Untreated plants of marigold)

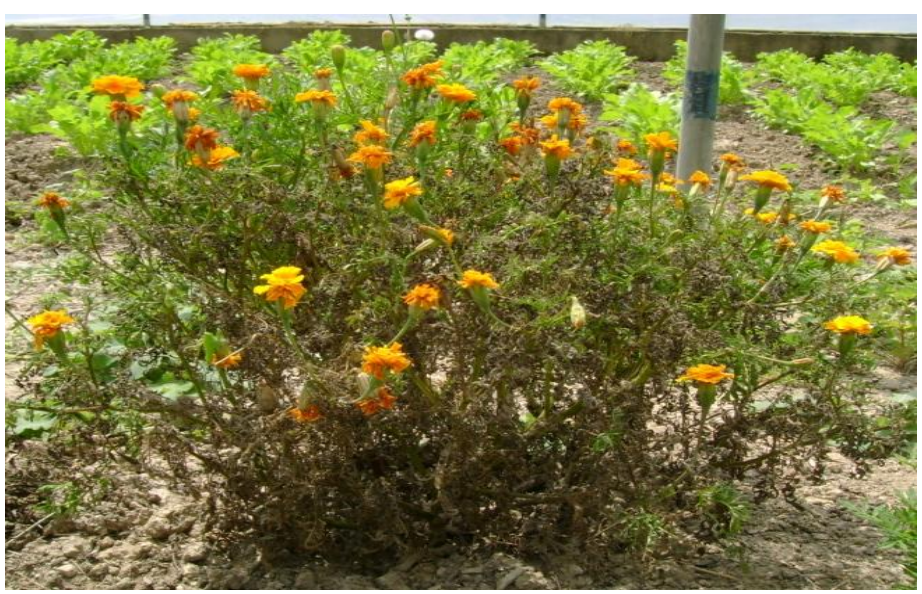

Table.3 Effect of the different bio-formulation on the disease severity of the Cercospora laef spot of marigold

\begin{tabular}{|l|c|c|c|c|}
\hline \multicolumn{1}{|c|}{ Bio-formulation } & \multirow{2}{*}{ Dose (\%) } & \multicolumn{2}{c|}{ Disease Severity (\%) } & \multirow{2}{*}{ Pooled } \\
\cline { 3 - 4 } & & $\mathbf{2 0 1 4}$ & $\mathbf{2 0 1 5}$ & \\
\hline Garlic Extract & 10 & $19.40(26.12)$ & $19.83(26.43)$ & $19.61(26.27)$ \\
\hline Saop Nut & 10 & $32.13(34.52)$ & $32.13(34.51)$ & $32.13(34.51)$ \\
\hline $\begin{array}{l}\text { Field formulation (Drake + Eucalyptus } \\
\text { +Bougainvillea + Pine needle + Robinia) }\end{array}$ & 10 & $30.76(27.09)$ & $31.43(27.56)$ & \multirow{2}{*}{$31.10(27.33)$} \\
\hline Garlic Extract + Cow urine +Soap Nut & 10 & $15.03(22.80)$ & $15.70(23.32)$ & $15.36(23.06)$ \\
\hline Cow urine & 10 & $17.00(24.34)$ & $19.13(25.92)$ & $18.07(25.14)$ \\
\hline Control & & $61.67(51.72)$ & $62.17(52.020$ & $61.91(51.84)$ \\
\hline Mean & & $29.67(31.10)$ & $30.40(31.63)$ & \\
\hline Effect & & C.D. & & \\
\hline Bio-formulation (BF) & & 0.252 & & \\
\hline Disease Severity (DS) & & 0.436 & & \\
\hline BF x DS & & 0.616 & & \\
\hline
\end{tabular}


Table.2 Effect of different fungicide on the disease severity of Cercospora leaf spot of marigold

\begin{tabular}{|c|c|c|c|c|}
\hline \multirow{2}{*}{ Fungicides } & \multirow{2}{*}{ Dose (\%) } & \multicolumn{2}{|c|}{ Disease Severity (\%) } & \multirow{2}{*}{ Pooled } \\
\cline { 3 - 4 } & $\mathbf{2 0 1 4}$ & $\mathbf{2 0 1 5}$ & $24.60(29.72)$ \\
\hline $\begin{array}{c}\text { Insignia } \\
\text { (Pyraclostrobin) }\end{array}$ & 0.1 & $24.36(29.57)$ & $24.83(29.87)$ & $28.03(31.96)$ \\
\hline $\begin{array}{c}\text { Matco (Metalaxyl } \\
\text { + Mancozeb) }\end{array}$ & 0.1 & $28.03(31.96)$ & $28.03(31.96)$ & $21.10(27.37)$ \\
\hline $\begin{array}{c}\text { Acrobat } \\
\text { (Dimethomorph } \\
\text { + Mancozeb) }\end{array}$ & 0.1 & $20.97(27.23)$ & $21.23(27.44)$ & $18.58(25.52)$ \\
\hline $\begin{array}{c}\text { Cabriotop } \\
\text { (pyraclostrobin }+ \\
\text { metiram) }\end{array}$ & 0.1 & $18.43(25.45)$ & $18.73(25.64)$ & $30.36(33.42)$ \\
\hline $\begin{array}{c}\text { Antracol } \\
\text { (Propineb) }\end{array}$ & 0.1 & $30.00(33.19)$ & $30.73(33.63)$ & $26.93(31.24)$ \\
\hline Cabrio (Metiram) & 0.1 & $26.60(31.03)$ & $27.67(31.46)$ & $25.28(30.17)$ \\
\hline $\begin{array}{c}\text { Alitte (Fosetyl } \\
\text { Al) }\end{array}$ & 0.1 & $25.17(30.09)$ & $25.40(30.20)$ & $17.41(24.66)$ \\
\hline $\begin{array}{c}\text { Captan 50 } \\
\text { (Captan) }\end{array}$ & 0.2 & $17.30(24.56)$ & $17.33(24.74)$ & $12.37(20.58)$ \\
\hline $\begin{array}{c}\text { Bavistin } \\
\text { (Carbendazim) }\end{array}$ & 0.1 & $12.47(20.66)$ & $12.27(20.49)$ & $62.07(51.23)$ \\
\hline $\begin{array}{c}\text { Control } \\
\text { Mean }\end{array}$ & & $61.93(51.88)$ & $62.23(52.06)$ & \\
\hline Effect & $26.57(30.56)$ & $26.87(30.75)$ & \\
\hline Fungicides (F) & & C.D. & & \\
\hline $\begin{array}{c}\text { Disease Severity } \\
\text { (DS) }\end{array}$ & & 0.26 & & \\
\hline F x DS & 0.77 & 0.46 & & \\
\hline & & & & \\
\hline
\end{tabular}

$15.36 \%, 18.07 \%$ and 19.61 respectively. While the least effective biofungicide were field formulation $(31.10 \%)$ and soap nut $(32.13 \%)$, when compared with the control $(62.07 \%)$.

The results of the field trails revealed that the among fungicides bavistin gave the best control against the Cercospora leaf spot of the marigold, similar results were recorded by the Barbetti (1987) and Veena et al., (2013) which is followed by the captan (Veena et al., (2013). A combination of the bio-forulation garlic extract + cow urine + soap nut was found effective in controlling the cercospora leaf spot which is followed by the cow urine, similar results were recorded by Venkataramana et al., (2009) working with foliar diseases of the mulberry plant. There was increased flower yield and quality of the flowers also increased.

\section{References}

Arora, R.K., Kamble, S.S. and Gangawane, L.V. 1992. Resistance to metalaxyl in Phytophthora infestans in Nilgiri Hills of South India. Int. Phytophthora Newslett., U.K., 18: 8. 
Asif, M. 2008. Effect of Various NPK Levels on Growth, Yield and Xanthophyll Contents of Marigold. MSc Thesis. Inst of Hort Sci., Univ of Agric, Faisalabad, Pakistan, p. 95.

Barbetti, M.J. 1987. Evaluation of fungicides for control of Cercospora zebrina on subterranean clover. Australian $J$. Experimental Agri., 27(1): 107 - 111.

Basu, S.D., Roy, S.K. 1975. Rotylenchulus sp. a new ecto parasitic nematode in ted soil. Two and Bud 22(1), (17) Em). In: Abst, C.F.H., Tocklia Experimental Station Horhat, Aaaaem, India, vol. 46. Breeding for Resistance to Fungal Pathogens. Canadian J. Botany, 68: 1039-1044.

Gangawane, L.V. 1981. Fungicides resistance in crop protection. Pesticides, 15(11): 1216.

Gomez, K.A and Gomez, A.A. 1986. Statistical procedures for agriculture research. 2nd edition, John Wiley and Sons, 680p.

Horsfall, J.G., and Barratt, R.W. 1945. An improved grading system for measuring plant diseases. Phytopathol., 35: 655.
McKinney, H.H. 1923. Influence of soil temperature and moisture on infection of wheat seedlings by Helminthosporium sativum. J. Agri. Res., 26: 195-217.

Pawar, I.S. 1971. Addition to the deuteromycetes fungi of Kolhapur district. J. Shivaji Univ., 4: 9.

Veena, K., Yashoda, R.H., Ganajaxi, M. and Kumar, A.G.V. 2013. Bioefficacy of fungicides against Cercospora canescens causing leaf spot of greengram. Crop Res., 46(1,2\&3): 74-78.

Waghmare, M.B., Waghmare, R.M. and Kamble, S.S. 2011. Bioefficacy of plant extracts on growth of Botrytis cinerea causing leaf blight of rose. The Bioscan, 6(4): 643.

Venkataramana, P., Narasimhamurthy, B., Krishna Rao, J.V. and Kamble, C.K. 2009. Efficacy of foliar sprays of vermiwash and cow dung wash on biochemical and yield attributes and yield of mulberry (Morus alba L.). Karnataka J. Agri. Sci., 22(4): 921-923.

\section{How to cite this article:}

Sunita Chandel and Vijay Kumar. 2017. Evaluating Fungicides and Biofungicide For Controlling Cercospora Leaf Spot On Marigold. Int.J.Curr.Microbiol.App.Sci. 6(5): 2072-2077. doi: https://doi.org/10.20546/ijcmas.2017.605.231 